\title{
Machine-learning phenotypic classification of bicuspid aortopathy: Did the mountain give birth to a mouse?
}

\author{
Jean Bachet, MD, FEBCTS
}

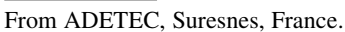 \\ Disclosures: Author has nothing to disclose with regard to commercial support. \\ Received for publication Oct 4, 2017; accepted for publication Oct 7, 2017; available ahead of print Nov 7, 2017. \\ Address for reprints: Jean Bachet, MD, FEBCTS, ADETEC 1, Place Marcel Legras, Suresnes 92150, France \\ (E-mail: jean.bachet@yahoo.fr). \\ J Thorac Cardiovasc Surg 2018;155:457-8 \\ $0022-5223 / \$ 36.00$ \\ Copyright (c) 2017 by The American Association for Thoracic Surgery \\ https://doi.org/10.1016/j.jtcvs.2017.10.028
}

In their article titled "Machine-Learning Phenotypic Classification of Bicuspid Aortopathy," Wojnarski and colleagues ${ }^{1}$ report on a large study aimed at establishing a correlation between the various types of dilatation of the proximal aorta with the presence and type of a bicuspid aortic valve. To achieve their project, they have used a sophisticated statistical method, the "machine-learning" phenotypic classification. Through this methodology, the authors determined 3 phenotypes of aortic lesions associated with the bicuspidy: the aortic root, ascending aorta, and aortic arch phenotypes.

As a whole, this well-written and clearly organized article is convincing. However, some points deserve some discussion.

Among those points, one seems particularly relevant and still unanswered: "Are aortopathies associated to bicuspid valves the result of an hemodynamic process or a genetic disease of the aortic wall?",2,3 This discussion has been going on for several decades and, with variable evolutions toward one theory or the other, remains unresolved. ${ }^{4}$ Unfortunately, the present study partly fails to shed some light on the matter.

As discussed by Wojnarski and colleagues, ${ }^{1}$ the description of 3 phenotypes might be excessive. It seems that the ascending aortic and aortic arch phenotypes could be 2 variants of the same phenotype and the consequence of the hemodynamic through the left ventricular outflow tract and the ascending aorta. This notion is not new and seems to be receiving some renewed interest. ${ }^{5}$ If we accept this pathophysiology, the slight difference in the location of the aortic dilatation could be explained only by the difference in the verticality of the ascending aorta and in the angulations between the left ventricle outflow track and the ascending aorta. According to those parameters, the stress of the vortex blood flow on the outer convexity would be applied more or less distally. This theory is supported by the fact that those lesions are mostly observed in older patients with a severe aortic valve stenosis.

Conversely, it appears that the root phenotype is observed in younger patients and is mostly associated with aortic

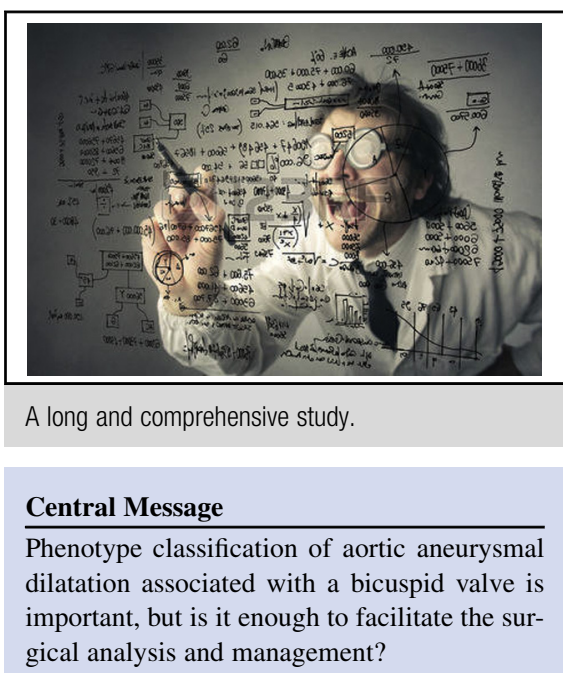

See Article page 461 .

valve regurgitation and annulus dilatation. The probability of a genetic connective tissue disorder origin of the root dilatation is likely as already speculated and demonstrated in several histologic and genetic studies. ${ }^{6-8}$

However, no clear recommendation for the surgical analysis and management of those lesions can be found. This illustrates the clear difference between surgery and science. The present article is clearly a sophisticated scientific one. Yet, one of the conclusions is that "Use of this machinelearning technology is not necessary for incorporating the characteristic of bicuspid aortopathy phenotype into future analyses, because by applying simple visual classification rules, we were able to obtain excellent concordance with the machine-learning results. Concordance between unsupervised clustering phenotype and visual classification by these rules was $94 \%$."1

So is eyeball analysis of the lesions informative enough and is all the scientific classification surgically useless? When should the root, ascending aorta, or hemi-arch be replaced?

Should we keep on replacing the root with composite grafts or valve-sparing procedures in root phenotypes of whatever size? Should we replace the ascending aorta only when its larger diameter reaches or exceeds $4.5 \mathrm{~cm}$ ? No clear answer is provided.

The answer still belongs to the surgeon and only to the surgeon (or the heart team). 


\section{References}

1. Wojnarski CM, Roselli EE, Idrees JJ, Zhu Y, Carnes TA, Lowry AM, et al. Machine-learning phenotypic classification of bicuspid aortopathy. J Thorac Cardiovasc Surg. 2018;155:461-9.

2. Girdauskas E, Borger MA, Secknus MA, Kuntze T. Is aortopathy in biscupid aortic valve disease a congenital defect or a result of abnormal hemodynamics? A critical reappraisal of a one-sided argument. Eur J Cardiothorac Surg. 2011;39:809-14.

3. Sievers HH, Sievers HL. Aortopathy in bicuspid aortic valve disease - genes or hemodynamics? or Scylla and Charybdis? Eur J Cardiothorac Surg. 2011;39: 803-4.

4. Robicsek F, Thubrikar MJ, Cook JW, Fowler B. The congenitally bicuspid aortic valve: how does it function? Why does it fail? Ann Thorac Surg. 2004;77:177-85.

5. Della Corte A, Bancone C, Quarto C, Dialetto G, Covino FE, Scardone M, et al. Predictors of ascending aortic dilatation with bicuspid aortic valve: a wide spectrum of disease expression. Eur J Cardiothorac Surg. 2007;31:397-405.

6. Bissell MM, Hess AT, Biasiolli L, Glaze SJ, Loudon M, Pitcher A, et al. Aortic dilation in bicuspid aortic valve disease: flow pattern is a major contributor and differs with valve fusion type. Circ Cardiovasc Imaging. 2013;6:499-507.

7. Fedak PW, de Sa MP, Verma S, Nili N, Kazemian P, Butany J, et al. Vascular matrix remodeling in patients with bicuspid aortic valve malformations: implications for aortic dilatation. J Thorac Cardiovasc Surg. 2003;126:797-806.

8. Girdauskas E, Geist L, Disha K, Kazakbahev I, Gross T, Schulz S, et al. Genetic abnormalities in bicuspid aortic valve root phenotype: preliminary results. Eur J Cardiothorac Surg. 2017;52:156-62. 